Bahasa Indonesia Prima, Vol 2. No. 2. 2020

e-ISSN: 2684-6780

\title{
METODE PEMBELAJARAN KOOPERATIF TIPE TGT UNTUK MENINGKATKAN PRESTASI BELAJAR BAHASA MANDARIN
}

\author{
oleh \\ Ivana (ivanawijaya92@gmail.com) \\ Fakultas Ekonomi-Universitas Prima Indonesia
}

\begin{abstract}
Abstrak-Metode Pembelajaran adalah suatu cara yang digunakan pendidik dalam proses pembelajaran untuk mencapai tujuan pembelajaran. Penelitian ini, metode pembelajaran yang digunakan adalah metode pembelajaran kooperatif tipe TGT (Teams-Games-Tournament) yang merupakan salah satu metode pembelajaran yang melibatkan peran siswa dan mengandung unsur permainan. Adapun tujuan penelitian ini adalah mengetahui peningkatan prestasi belajar siswa SMA kelas $\mathrm{X}$ dengan menggunakan metode pembelajaran TGT terhadap kemampuan menggunakan kosakata HSK 3. Hasil penelitian ini menunjukkan bahwa metode pembelajaran TGT yang diterapkan di kelas X MIA A memiliki rata-rata nilai 77.93, sedangkan kelas X MIA B yang menggunakan metode pembelajaran konvensional memiliki rata-rata nilai 64.66.
\end{abstract}

Kata-kata kunci: metode pembelajaran, TGT, prestasi belajar.

\section{A. PENDAHULUAN}

Bahasa merupakan suatu media penghubung yang digunakan manusia dalam membangun sebuah hubungan, sehingga menguasai bahasa adalah sebuah keharusan. Dan tak dipungkiri pada zaman modern ini, bukan hanya bahasa Inggris saja yang digemari, namun bahasa Mandarin juga semakin hari semakin diminati. Pada saat ini bahasa Mandarin telah menjadi bahasa Internasional kedua. Hal ini menyebabkan banyaknya orang ingin menguasi bahasa Mandarin dengan baik.

Namun, untuk mempelajari suatu ilmu khususnya bahasa, bukan hanya dibutuhkan pendidik yang berkualitas, namun lebih diperlukan minat belajar siswa yang didukung dengan fasilitas dan metode pembelajaran yang tepat, sehingga pembelajaran dapat menjadi efektif. Pendidik dituntut untuk dapat menentukan dan menggunakan metode pembelajaran yang paling tepat dan paling sesuai dengan siswa, sehingga minat belajar siswa dapat meningkat dan tujuan pembelajaran pun tercapai, khususnya dalam pelajaran bahasa Mandarin.
Proses pembelajaran didalam kelas $\mathrm{X}$ SMA Methodist Charles Wesley biasanya hanya mendengarkan penjelasan pendidik, mencatat catatan yang penting, mengerjakan tugas yang diberikan, dan membahas tugas tersebut, tidak ada hal yang menunjang untuk meningkatan semangat belajar siswa dan akhirnya menyebabkan siswa menjadi jenuh dan berujung kemalasan dan prestasi belajar siswa menurun. Metode pembelajaran ini adalah metode pembelajaran konvensional, yang mana peran guru lebih aktif dan siswa lebih pasif. Sedangkan, siswa SMA X Methodist Charles Wesley merupakan siswa yang sangat aktif dan suka berkompetisi, maka dari itu berlatar belakang masalah ini, peneliti mencoba menggunakan metode pembelajaran TGT untuk meningkatkan prestasi belajar dalam pelajaran bahasa Mandarin. Prestasi belajar yang dicapai merupakan salah satu cara untuk melihat kemampuan siswa setelah mendapatkan pembelajaran.

Menurut Slavin (dalam Isjoni, 2011: 15) menyatakan bahwa "pembelajaran kooperatif adalah suatu model pembelajaran 
dimana siswa belajar dan bekerja sama dalam kelompok-kelompok kecil secara kolaboratif yang anggotanya terdiri dari 4-6 orang dengan struktur kelompok heterogen." Metode Pembelajaran Teams Games Tournament (TGT) adalah salah satu metode pembelajaran kooperatif yang menekankan adanya kerjasama antar anggota kelompok untuk mencapai tujuan belajar. Komponen yang terdapat dalam metode pembelajaran TGT adalah presentasi kelas, belajar kelompok, permainan, turnamen/perlombaan, dan penghargaan kelompok.

1. Metode Pembelajaran Kooperatif

Metode Pembelajaran adalah suatu cara yang digunakan pendidik untuk mencapai tujuan pembelajaran. Menurut Agus Suprijono (2009:46), metode pembelajaran adalah pola yang digunakan sebagai pedoman dalam merencanakan pembelajaran di kelas maupun tutorial.

Artzt \& Newman dalam Trianto (2009:56) menyatakan bahwa dalam belajar kooperatif siswa belajar bersama sebagai suatu tim dalam menyelesaikan tugas-tugas kelompok untuk mencapai tujuan bersama. Jadi, setiap anggota kelompok memiliki tanggung jawab yang sama untuk keberhasilan kelompoknya.

Adapun variasi dalam metode pembelajaran kooperatif adalah TGT, STAD, JIGSAW, GI dan pendekatan struktural.

\section{Metode Pembelajaran Team Games Tournament ( TGT )}

Metode Pembelajaran TGT merupakan suatu metode pembelajaran yang dikembangkan secara asli oleh David De Vries dan Keath Edward pada tahun 1995, yang merupakan suatu metode yang mengembangkan kerja sama antar personal.Metode pembelajaran TGT memiliki banyak kesamaan dengan metode pembelajaran STAD, perbedaannya hanya di unsur permainan, yang mana metode pembelajaran TGT menambahkan dimensi kegembiraan yang diperoleh dari permainan.

Metode pembelajaran TGT sangat cocok digunakan untuk berbagai macam pelajaran, ilmu eksak, ilmu sosial maupun ilmu bahasa dan cocok digunakan untuk segala jenjang, dari jenjang SD, SMP, SMA hingga perguruan tinggi.

Adapun keuntungan dari metode pembelajaran TGT adalah sistem permainan dalam kelompok, yang sangat bermanfaat khususnya untuk mengajarkan aspek-aspek kognitif tingkat tinggi seperti analisis, dan dengan adanya persaingan, maka akan muncul motivasi yang kuat bagi siswa, dan dengan sistem permainan ini akan membentuk suatu situasi belajar yang menyenangkan yang akan sangat mempengaruhi tingkat konsentrasi, kecepatan menyerap materi pelajaran, jumlah pelajarandan kematangan pemahamannya.

Lima komponen dalam pelaksanaan metode pembelajaran kooperatif tipe TGT (Slavin, 2008:161):

a) Presentasi kelas.

b) Pembagian kelompok.

c) Permainan.

d) Pertandingan atau turnamen.

e) Penghargaan tim.

\section{Metode Pembelajaran dan Peningkatan Prestasi Belajar Siswa}

Setiap metode pembelajaran, baik metode pembelajaran konvensional maupun pembelajaran kooperatif memiliki ciri khas, tersendiri, dan setiap metode pembelajaran mendukung pencapaian prestasi belajar siswa. Namun, tidak ada satu pun metode pembelajaran yang cocok untuk semua materi pembelajaran ataupun siswa.

Slavin (2005:33) mengemukakan bahwa tujuan yang paling penting dari pembelajaran kooperatif adalah untuk memberikan para siswa pengetahuan, 
konsep, kemampuan, dan pemahaman yang mereka butuhkan, supaya bisa menjadi anggota masyarakat yang bahagia dan memberikan kontribusi. Sejak semula, penelitian mengenai pembelajaran kooperatif telah memperlihatkan bagaimana strategi ini bisa mengembangkan pencapaian yang bisa dibuat para siswa. Pembelajaran kooperatif memang menunjukkan peningkatkan pencapaian, namun yang paling penting bahwa pembelajaran kooperatif harus ada pada tempatnya jika menginginkan pengaruh dan pencapaian maksimal.

Metode pembelajaran kooperatif tipe TGT memiliki keunggulan dan kelemahan dalam implementasinya terutama dalam hal pencapaian hasil belajar dan efek psikologis bagi siswa.

Dalam hal ini, siswa kelas X SMA Methodist Charles Wesley Medan memiliki jiwa berkompetisi yang kuat dan sangat aktif didalam prose pembelajaran. Jika sifat demikian hanya digunakan untuk mendengar penjelasan pendidik, mencatat catatan, dan membuat tugas dalam proses pembelajaran, maka akan menyebabkan penurunan minat belajar siswa dan tidak akan ada lagi sesuatu yang memotivasi siswa untuk belajar, khususnya pelajaran bahasa Mandarin yang merupakan sebuah bahasa asing yang sangat berbeda dengan bahasa sehari-hari siswa, karena siswa lebih sering menggunakan bahasa Indonesia ataupun bahasa Inggris dalam berkomunikasi, sehingga metode pembelajaran yang kurang tepat akan membuat pelajaran bahasa Mandarin menjadi semakin sulit dan menjenuhkan. Maka dari itu, metode pembelajaran kooperatif tipe TGT mungkin sesuai dengan siswa kelas X SMA Methodist Charles Wesley Medan.

\section{Hipotesis}

Penerapan Metode Pembelajaran kooperatif tipe TGT dapat meningkatkan prestasi belajar siswa dalam pelajaran bahasa Mandarin.

\section{B. METODE PENELITIAN}

\section{Rancangan Penelitian}

Sugiono (2013:107) menyatakan bahwa penelitian eksperimental dapat digunakan untuk mencari pengaruh perlakuan tertentu terhadap yang lain dalam kondisi yang terkendali, maka dalam penelitian ini, peneliti menggunakan penelitian eksperimen. Dan dalam penelitian ini, peneliti menggunakan angka-angka dan analisis menggunakan statistik untuk menguji hipotesis, maka metode yang digunakan dalam penelitian ini adalah metode kuantitatif.

Tabel 1. Rancangan Penelitian

\begin{tabular}{|c|c|c|c|}
\hline Grup & Pretest & $\begin{array}{c}\text { Variabel } \\
\text { bebas }\end{array}$ & Posttest \\
\hline E & $\mathrm{Y}_{1}$ & $\mathrm{X}$ & $\mathrm{Y}_{2}$ \\
\hline $\mathrm{C}$ & $\mathrm{Y}_{1}$ & - & $\mathrm{Y}_{2}$ \\
\hline
\end{tabular}

2. Populasi dan Sampel

Adapun populasi penelitian ini adalah siswa kelas X SMA Methodist Charles Wesley berjumlah 58 orang. Sampel yang digunakan adalah Sampel Cluster Sampling. Sampel Cluster Sampling adalah teknik pengambilan sampel dimana pemilihan mengacu pada kelompok bukan pada individu.

Pada penelitian kali ini, siswa kelas $\mathrm{X}$ MIA A yang siswanya berjumlah 29 orang akan diberi pengajaran dengan menggunakan Metode Pembelajaran Kooperatif tipe TGT, sedangkan siswa kelas X MIA B dengan jumlah siswa 29 orang akan diberi pengajaran dengan menggunakan Metode Pembelajaran Konvensional.

\section{Instrumen Penelitian}

Pada penelitian ini, peneliti menggunakan instrumen Tes dalam meneliti. Tes berupa pilihan berganda memiliki nilai objektif yang lebih tinggi 
Bahasa Indonesia Prima, Vol 2. No. 2. 2020

e-ISSN: 2684-6780

dibandingkan tes lainnya dan hanya memiliki 1 jawaban, maka peneliti membuat tes ini dalam bentuk pilihan berganda yang terdiri dari 20 butir soal dengan 5 buah pilihan di setiap soalnya. Tes ini dibuat langsung oleh guru bidang studi bahasa Mandarin untuk mengukur kemampuan siswa dalam memahami kosakata HSK 3.

\section{Prosedur Pengumpulan Data}

Adapun prosedur untuk mengumpulkan data yang dilakukan adalah:Pretest, Pengajaran, dan Posttest. Pretest dilakukan pada awal bulan Januari 2019 untuk mengetahui kemampuan awal siswa. Kemudian dilanjutkan dengan pengajaran yang dilakukan dalam 8 pertemuan, yaitu dari pertengahan bulan Januari sampai bulan Maret 2019. Setelah itu, dilanjutkan dengan pemberian posttest untuk menguji hasil belajar siswa.

\section{HASIL PENELITIAN DAN PEMBAHASAN}

1. Hasil Penelitian

Data Kelas $X$ MIA A yang menggunakan metode pembelajaran TGTada 29 data yang dapat disimpulkan menjadi: Nilai pretest tertinggi adalah 40 dan nilai terendah adalah 0 , dengan rataratanya adalah 20.34. Sedangkan nilai tertinggi posttest adalah 100 dan nilai terendahnya adalah 50, dengan rata-ratanya adalah 77.93 .

Sedangkan data Kelas X MIA B yang menggunakan metode pembelajaran konvensional ada 29 data juga dan dapat disimpulkan menjadi: Nilai pretest tertinggi adalah 50 dan nilai terendah adalah 5, dengan rata - ratanya adalah 23.97. Sedangkan nilai tertinggi posttest adalah 100 dan nilai terendahnya adalah 45 , dengan rata-ratanya adalah 64.66.

Untuk menggunakan uji t-test, maka uji normalitas dan uji homogenitas diperlukan dalam penelitian.

\section{Uji Normalitas}

Nilai normalitas (Lhitung) kelas X MIA A adalah 0.10 dan nilai normalitas (Lhitung) kelas X MIA B adalah 0.15. Sedangkan $\mathrm{L}_{\text {tabel }}$ adalah 0.161 .

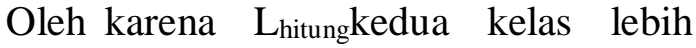
rendah dari nilai $L_{\text {tabel }}$ [L $L_{\text {hitung }} X$ MIA $\mathrm{A}(0.10)<\mathrm{L}_{\text {tabel }}(0.161)$ dan $\mathrm{L}_{\text {hitung }} \mathrm{X}$ MIA B $\left.(0.15)<\mathrm{L}_{\text {tabel }}(0.161)\right]$, maka hasil yang didapat adalah normal.

\section{Uji Homogenitas}

Nilai homogenitas ( $\left.F_{\text {hitung }}\right)$ dari kedua kelas adalah 0.97. Sedangkan $F_{\text {tabeladalah }}$ 1.84 .

Hasil terserbut menunjukkan bahwa Fhitunglebih kecil dari $F_{\text {tabel }}$ $\left[\mathrm{F}_{\text {hitung }}(0.97)<\mathrm{Ft}_{\text {abel }}(1.84)\right]$, maka hasil yang didapat itu adalah homogen.

\section{Uji Hipotesis}

Uji hipotesis dilakukan dengan menggunakan uji t-test. Kriteria yang digunakan dalam pengujian dilakukan berdasarkan perbandingan nilai signifikan

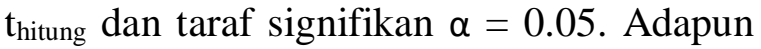

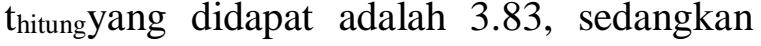
$\mathrm{t}_{\text {tabel }}$ adalah 3.46.

Hasil tersebut menunjukkan bahwa nilai $t_{\text {hitung }}$ lebih besar dari nilai $t_{\text {tabel }}(3.83>3.46)$, dapat disimpulkan bahwa metode Team Games Tournament (TGT) dapat lebih meningkatkan prestasi belajar siswa terhadap kemampuan menggunakan kosakata HSK 3.

Adapun hasil penelitian yang didapat adalah metode pembelajaran kooperatif tipe TGT dapat lebih meningkatkan prestasi belajar siswa dibandingkan dengan metode pembelajaran konvensional.

\section{Pembahasan}

Hasil penelitian ini menyatakan bahwa metode pembelajaran kooperatif tipe TGT dan metode pembelajaran konvensional sama-sama memiliki pengaruh untuk meningkatkan prestasi belajar siswa dalam menggunakan kosakata HSK 3, sehingga disimpulkan bahwa metode pembelajaran 
kooperatif tipe TGT dan metode pembelajaran konvensional cocok untuk digunakan dalam meningkatkan prestasi belajar siswa SMA X sekolah Methodist Charles Wesley Medan, namun sesuai dengan hasil yang didapat, metode pembelajaran kooperatif tipe TGT lebih baik dibanding metode pembelajaran konvensional, karena metode pembelajaran kooperatif tipe TGT lebih menarik dan interaktif, yang mana didalam proses pembelajaran terdapat komponen presentasi kelas, pembagian kelompok, permainan dan kompetisi, yang menyebabkan siswa menjadi lebih aktif dan suasana belajar didalam kelas pun menjadi lebih semangat, sehingga motivasi belajar siswa pun meningkat dan prestasi belajar siswa pun meningkat.

\section{KESIMPULAN}

Berdasarkan hasil analisis data dan pengujian hipotesis, maka dapat ditarik kesimpulan bahwa Metode Pembelajaran kooperatif tipe TGT dapat meningkatkan prestasi belajar bahasa Mandarin siswa kelas X SMA Methodist Charles Wesley Medan.

DAFTAR PUSTAKA

Agus, S. 2009. Cooperative Learning: Teori dan Aplikasi PAIKEM. Yogyakarta: Pustaka Pelajar.
Isjoni. 2009. Cooperative Learning Efektivitas Pembelajaran Kelompok. Bandung: Alfabeta.

Slavin, R. 1995. Cooperative Learning : Theory, research, and Practise. Boston: All yand and Bacon Publishers.

-----------. 2005. Cooperative Learning: Teori, Riset dan Praktik. Bandung: Nusa Media.

------------. 2008. Cooperative Learning: Teori, Riset dan Praktik. Bandung: Nusa Media.

Sugiyono. 2011. Pengantar Evaluasi Pendidikan. Jakarta: Rajawali Pers.

Trianto. 2009. Mendesain Model Pembelajaran Inovatif Progresif. Jakarta: Kencana Predana Media Group.

Zhu. 2003. Butong Gaoxiao Lanqiu Xuan Xiangke Yunyong Linghui Jiaoxuefa de Shixian Yanjiu. Medan: Shubei Daxue. 